\title{
The Ethnic Image of Chinese Mongolian Films
}

\author{
Zhikun Zhang \\ School of Fashion Media, Jiangxi Institute of Fashion Technology, Nanchang, China \\ Email: 852637948@163.com
}

How to cite this paper: Zhang, Z.K. (2021) The Ethnic Image of Chinese Mongolian Films. Open Access Library Journal, 8: e8087. https://doi.org/10.4236/oalib.1108087

Received: October 18, 2021

Accepted: November 6, 2021

Published: November 9, 2021

Copyright $\odot 2021$ by author(s) and Open Access Library Inc.

This work is licensed under the Creative Commons Attribution International License (CC BY 4.0).

http://creativecommons.org/licenses/by/4.0/

\begin{abstract}
Inner Mongolian film has always played a significant role in the history of Chinese ethnic film. Located in northern China, Inner Mongolia Autonomous Region is home to unique geographical features and customs which make it an important sample for the study of Chinese regional film. In addition to character-developing of Mongolian people, the grassland culture shaped by the geographical environment also provided rich artistic resources for the creation of Chinese ethnic films. The result is more unforgettable artistic image of the horseback people. Through organizing the characteristics of Inner Mongolia's Geo-culture, the paper hopes to analyze the reasons for the creation of the Mongolian film image.
\end{abstract}

\section{Subject Areas \\ Art, Culture}

\section{Keywords}

Geo-Culture, Mongolian Film, Grassland Culture

\section{Introduction}

Mongolia has a strong ethnic identity. Years of creation and communication by artists have made numerous ethnic symbols familiar to the public, such as beautiful Mongolian costumes, running horses and muscular Mongolian men, which can be considered as part of unique Mongolian landscape. Geography, culture, and history are used as reference directions in the study of Mongolian films in China, therefore, a geo-culture study of Mongolian films is formed. It is home to magnificent geography, unique lifestyle of the ethnic minorities and diverse ethnic culture. All these have offered golden opportunities for Chinese filmmakers of all generations who have brought audiences an exotic visual feast.

Both boundless grasslands and barren deserts of Inner Mongolia help form 
the character of the Mongolian people. The geographical environment has greatly influenced their emotions and actions, producing a cultural phenomenon with local characteristics. Since the emergence of the first Mongolian film "Storm on the Border" [1], the nomadic Mongolian people, who live on the grasslands, have been admired and valued by film makers who have created many film images of Mongolians.

\section{Geographical Characteristics of Mongolian Culture}

As a matter of fact, the natural environment has a profound influence on the formation of the regional ethnic character. Geographical environment is of great significance in the formation of a regional culture. The emergence of a nation is inseparable from its land, and the national character is also being shaped by the geographical environment.

The Mongolian people have long lived in bad condition in the northern border areas where the vegetation is vulnerable. By virtue of wisdom and endeavor, the Mongolian ancestors survived the extreme climate of drought and cold. Fighting for land in the harsh living conditions, the Mongolian people have formed indomitable character in the struggle against the nature. In "The Spring of Desert', a film of 1975, the selfish Commune President instigated the herdsmen to sell their livestock and go hunting in front of the terrible sand and wind. When others were hesitant, Narenhua came out boldly, saying "if we can change through afforestation and water-control, we can control the sandy desert." Despite the windblown sand never encountered before, Narenhua rose to the challenge and made it through supported by the masses. It proves that the film itself is an inseparable part of the geo-culture. In the film "Heavenly Grassland", Baorima also said: "We Mongolians are like a grass, frozen and fired, but we can rebuild life when spring comes." The Mongolian people in the film are brave enough to face the difficulties and challenges, which is the most appropriate interpretation of their tenacious character.

As shown in Figure 1, located in the inland semi-arid zone, the Mongolian plateau features scarce rain and great temperature difference, which means the

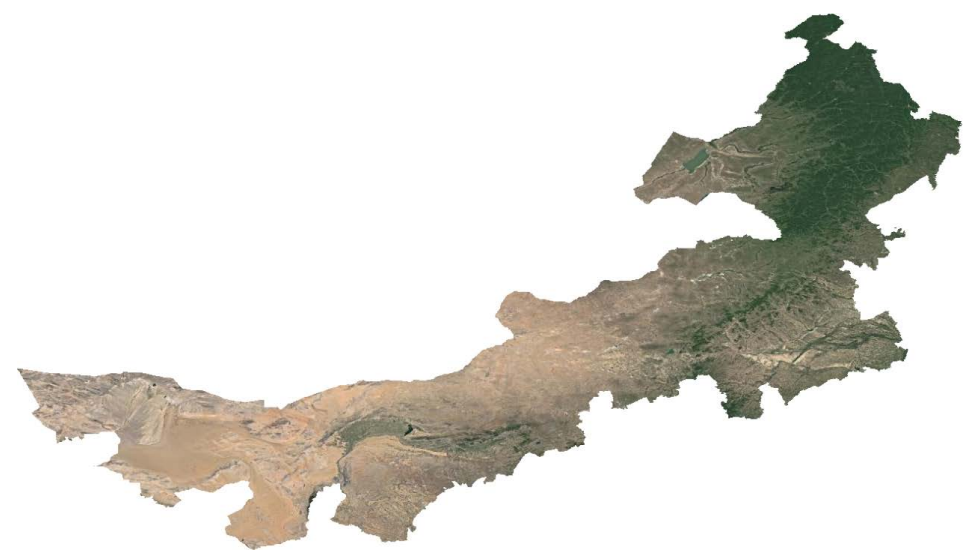

Figure 1. Topographic map of Inner Mongolia. 
place is not suitable for crops cultivating. Therefore, the Mongolian people must rely on horseback herding to obtain water and grass resources. Due to many difficulties, the Mongolian people know the preciousness of life, thus developing their philosophy of reverence for life. In their eyes, life is worthy of respect, so Mongolians have the habit of adopting children, and there are very few orphans there. Mongolians are so unsophisticated that they treat the adopted children as their own. In their mind, the whole steppe is their home and the children on the steppe are their own children. In My Mongolian Mother (Figure 2), directed by Ning Cai, this idea of cherishing life is given a more selfless touch. The focus of film is a Shanghai orphan sent to Inner Mongolia to reflect the great love of a Mongolian adoptive mother. It is a fact that the Inner Mongolian grasslands accept and raise three thousand Shanghai orphans. From the perspective of the value of life, people living in there show their respect and salute to life [2].

Mongolians respect life and love animals. In spite of wolves as enemies, they maintain compassion. In the film "Heavenly Grassland", Xuerigan lassoed the wolf with a rope and made the wolf lose its aggressiveness by constantly shaking to protect the flock of sheep. Instead of killing the wolf at once, he reprimanded the wolf to "go far away", finally releasing it to the grassland. Finally, the wolf is released to the grassland. It not only conforms to the simple lifestyle of Mongolians, but also shows the virtue of cherishing life.

\section{The Image of Mongolian People in the Perspective of the other}

In the perspective of "the other", the Mongolian people, as an ethnic minority in the north, are inevitably imagined as "the other". The unique living environment of the Mongolian plateau full of mystery can be considered as the most exotic place in the eyes of the outside world. This exotic landscape has become the main object of the film creators, such as the representation of natural scenery,

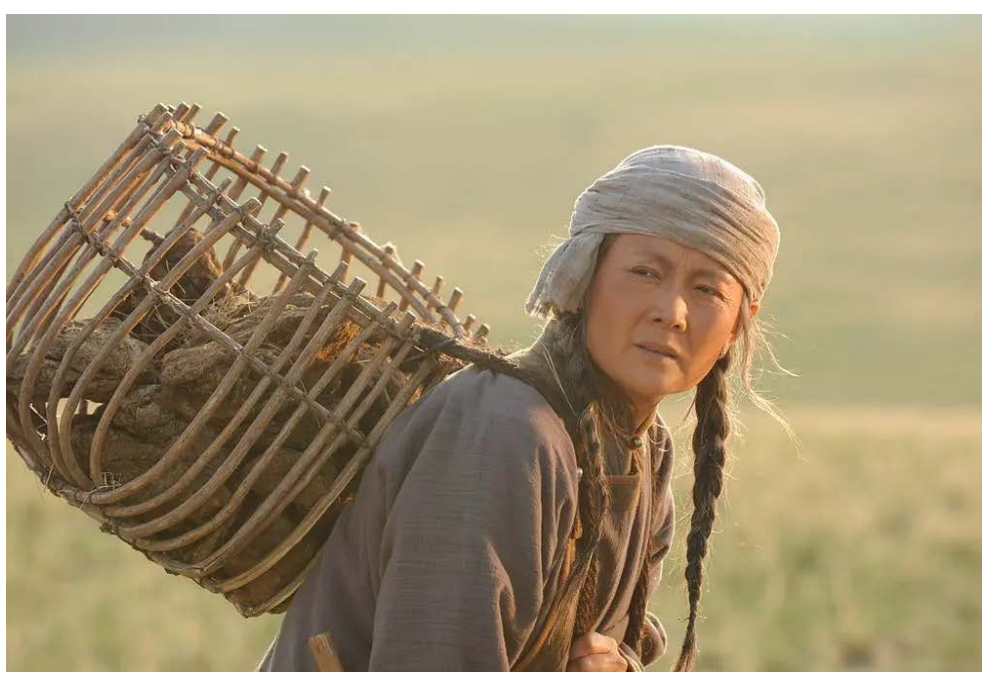

Figure 2. Still of My Mongolian Mother. 
the portrayal of ethnic customs, and the reemergence of myths and legends. On one hand, the landscape meets the aesthetic demands of the audience. On the other hand, it reveals the perspective of the non-Mongolian creators on the Mongolian culture.

There are two typical Mongolian images first appearing in literature: strong and brave Mongolian men as well as tough and kind Mongolian women. When a sense of nationalization emerged in film production, these images were maintained. There is a historical complex and hero worship in Mongolian films. The protagonist of Storm on the Border is Diluwa, a Mongolian young man who dares to fight with Japanese secret agents, showing a brave and resourceful image of Mongolian men on the screen. Besides, Heavenly Grassland, directed by Saifu and Maelis, begins the film with a direct off-screen description of Baorima: "Lake Dali nurtures Tenggeli Tala. It is pure and beautiful, full of warmth and gentleness, like the Mongolian woman I would call 'Amah'." Although these two roles are slightly stereotypical, they are a summary of the character and artistic treatment of the Mongolian images as a matter of fact.

With a long history, The Mongolian people have many heroic stories over time. Gada Meilin, a 2002 film by a Han director Feng Xiaoning, takes the legendary Mongolian hero Gada Meilin as the main character, telling a historical story of his leading the people of the grasslands to fight against the feudal monarchy and Japanese invaders. Based on the historical widely-read figures in the Horqin Grassland, the film focuses on portraying the Mongolian heroes while bringing the magnificent scenery to the audience. The film not only has the female protagonist Mudan in the herd of horses galloping with a lasso pole, but also a wrestling competition between Gada and Bartel in the Naadam Conference. The director took the Horqin Grassland as a mirror image to show the natural landscape of the birch forest, the Yellow River, and the grasslands in a romantic way. The film shows the bravery of the Mongolian people fighting against the feudal warlords and foreign invaders and tells the beautiful humanity under the war.

In addition to Chinese ethnic film creators, foreign film creators are also attracted by Mongolian culture. Combining the mysticism of Western culture, they recreate the myths and legends of Mongolian culture. There is a legend that Mongolians are the descendants of "the Wolf and the Mongols" [3], and the wolf occupies a special place in Mongolian culture. In Mongol: The Early Years of GenghisKhan, directed by Sergey Bodrov, the source power of Temujin is explained as the gift of Immortality, which is represented by wolves. In the film Wolf Totem by Jean-Jacques Annaud, Biliger stated that Genghis Khan was able to defeat thousands of armies in the world because he "learned the secret of warfare from the wolves". Mongol: The Early Years of Genghis Khan, a film about Mongolian history from the perspective of the typical other, was later nominated for an Academy Award for Best Foreign Language Film. It not only presented the early life of Temujin in a more objective and epic way, but also fit the Western imagination of Mongolian tribal warfare. 


\section{The Image of Mongolian People in Urban Space}

As the wave of globalization has disrupted traditional geopolitical structures, the cultural subjects of nationalism have begun to seek cultural identity different from stereotype. The deepening of urbanization in China also began to change the way of life of the Mongolian people: some Mongolians moved from the grasslands to the cities. After experiencing industrial and commercial civilizations, these Mongolians experienced the pain of identity transformation through the collision of different cultures. The process of becoming "citizens" from "herders" constitutes the image of urban Mongolians in the new era of film creation.

In the film "Urtin Duu" directed by Hasz Chaolu, Batu, the husband of singer Qiqige, reached Beijing from the grasslands. Accustomed to riding horses, Batu did not wear a seatbelt and then was stopped by the traffic police. Later he had a conflict with the equestrian club when he stopped a horse trainer beating the horse with a whip. Putting a Mongolian man from the grasslands in a modern city, the director managed to reflect cultural differences with different identity. As a matter of fact, Batu's discomfort in Beijing can be seen as an expression of the contradiction between nomadic and urban culture.

When the first generation of Mongolians came to live in the fast-paced, orderly city, their offspring grew up in the urban area. They carry the cultural genes of their fathers to a greater or lesser extent, but they cannot fully inherit the character and customs of their own ethnic group as they grow up under the influence of urban culture. The mainstream popular culture outshines the minority culture, and these young Mongolians growing up in the city deeply feel the contradiction and integration between ethnic culture and urban culture. The film A Simple Goodbye (Figure 3) is directed by a young Degena Yun, the daughter of two famous Mongolian directors, Saifu and Lisi Mai, and she is the second

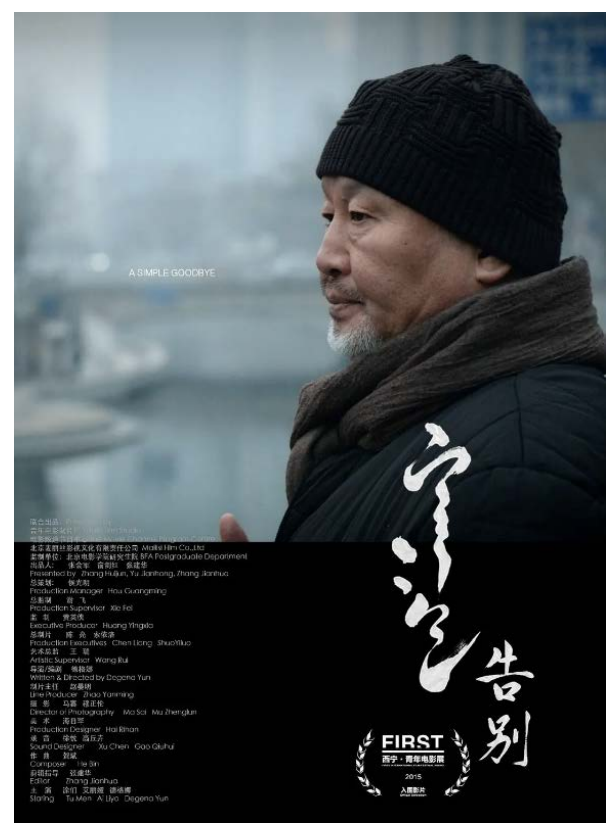

Figure 3. Poster of A Simple Goodbye. 
generation Mongolian and filmmaker. "She is the daughter of two famous Mongolian directors, Saifu and Lisi Mai. The film tells the story of her father's last moments in life, not only a tribute to Saifu, but also to the older generation of Mongolian filmmakers. The old generation of Mongolian directors who once created brilliant artistic achievements are saying goodbye. While expressing their worries and reflections on the future development of Mongolian films, they convey their thoughts on their own culture and art to their children. It is obvious that the mission of carrying forward their films is passed to the younger generation of Mongolian directors.

Language can be considered as an important symbol of national identity. Mongolian is the native language of the Mongolian people. In the film $A$ Simple Goodbye, that Chinese and Mongolian alternate in different scenes is just like the ethnic culture wandering in the urban civilization. Even after living in the city for a long time, fathers often speaks in Mongolian, while Degena Yun, as a younger generation, can only understand but not speak. As Saifu and Bayaneruul chatted in Mongolian in the studio's screening room, they recalled the old days and expressed their concern about the fading of their own culture. As Saifu said, "What's the meaning of building so many concrete yurts on the grasslands and chatting with Chinese words all day long." These worries add sadness to the image of urban Mongolians, conveying Degena Yun's reflection on the identity of urban Mongolians.

If Saifu and Lisi Mais' film is a profound understanding and interpretation of Mongolian culture, Degena Yun's is a different understanding of ethnic culture by a new generation of Mongolian filmmakers. Different from her parents, Degena Yun tried to weaken the ethnic symbols in A Simple Goodbye and told a story of her father's last days straightforwardly-an old Mongolian director's daily life in the city. He would argue with his wife over the concrete yurt built on the grassland, and fell guilty for the film's cliff falling scene. In the film, Saifu was often lonely and desolate, which contrasted with the bustling urban area. When presenting Mongolian urban life, Degena Yun gave her emotions and views, which made simple plots more realistic, thus reflecting the sense of anxiety and powerlessness of Mongolians facing urban life.

\section{Regional Transformation of "De-spectacle"}

Ethnic minority films put more emphasis on the study of the history and culture of the ethnic group itself. The specific natural ecological and geopolitical background, combining with the socio-historical context, form a unique ethnic style in terms of narrative subjects and character images. Years of exploration and practice prove that the narrative style of ethnic films has gradually moved from the mainstream national consciousness to the expression of material and intelligent life in the new socialist era. Therefore, the film images of Mongolians have transformed into urban citizens. Meanwhile, Mongolian directors no longer intend to create Mongolian ethnic characteristics for miraculous grassland sce- 
nery. Mongolian films has also transformed into regional creation.

In this paper, "de-spectacle" refers to a shift in the film's perspective from different cultures to the commonality of Mongolians as members of society. In fact, "de-spectacle" has been used in Mongolian films. In Faraway yurt, a Sino-Mongolian co-production film in 2001, a Mongolian girl fell in love with a seriously wounded soldier from Mongolia, a country. The soldier returned to Mongolia along with his troops, while the Mongolian girl raised their child alone with miss. Based on Inner Mongolia prairie, the film shows a sincere love story. By weakening ethnic tendency, the creator focused on a universal love story. The female protagonist in the film can be considered as a mirror of countless girls who believe in love and hold on to it. Instead of "de-spectacle", the consideration of the creative team and the audience rendered the choice of the place.

In Old Beast, the director Zhou Ziyang cast Tu Men as a dimensional figure, Lao Yang. Although Tu was almost a film symbol of Mongolian man, the film did not make the ethnic identity of Lao Yang clear. Even his living place can be roughly estimated from accent, the film still downplayed ethnic scenes, telling a story of Lao Yang who used to be wealthy becoming a bankrupt hobo and waging a legal battle with his children. Instead of showing ethic spectacles, Old Beast focused on urban individuals, portraying a complex tragic figure through the narration.

\section{Conclusions}

Overall, the grassland culture, as a cultural product of the nomadic Mongolian people living with the natural environment for a long time, can be considered as a precious artistic resource. In the future, Mongolian films should not be limited to the presentation of ethnic customs and expression of ethnic feelings. Besides, they should put more emphasis on the shaping of Mongolian images with the human nature, thus realizing the transformation from ethnic films to regional films.

Of course, there are still some limitations in the study of Mongolian films due to the author's shortage of vision and theory. For example, the development of film technology and the support of national industrial policies are also part of the future problems to be solved in terms of works of art with industrial properties.

\section{Conflicts of Interest}

The author declares no conflicts of interest.

\section{References}

[1] Li, Z.G. (2019) Revolutionary Narrative, Historical Root-Finding and Realistic Criticism: An Overview of the Type Evolution of Mongolian Films Since the Reform and Opening-Up. Contemporary Cinema, 9, 161-164.

[2] Rao, S.G. (2010) A Tribute to Life: Review of My Mongolian Mother. Contemporary 
Cinema, 6, 21.

[3] Sumir (2019) Art Panorama: The Aesthetic Dimension of Mongolian Films in the 21st Century. Movie Review, 2, 16-19. 